\title{
Immunohistochemical Analysis of Neuroendocrine Differentiation in Prostate Cancer
}

\author{
Eiwa Ishida Mitsutoshi Nakamura Keiji Shimada Masato Tasaki \\ Noboru Konishi \\ Department of Pathology, Nara Medical University School of Medicine, Kashihara, Japan
}

\section{Key Words \\ Prostate cancer • Neuroendocrine cells • Calcitonin • \\ Androgen receptor $\cdot$ Immunohistochemistry}

\begin{abstract}
Objective: To clarify the significance of neuroendocrine differentiation in prostate cancer. Methods: We immunohistochemically examined 96 samples of prostatic cancers obtained from radical prostatectomies using a specific neuroendocrine marker and various neuropeptides, as well as markers for cell proliferation, angiogenesis and androgenreceptor expression. Results: We frequently found neuroendocrine cells in atrophic glands with or without chronic inflammation in nontumorous tissues. Neuroendocrine cells were detected in $36.5 \%$ of prostate cancer samples overall, but had no significant correlation to angiogenesis, cell proliferation or biochemical recurrence. However, patients with a high frequency of neuroendocrine cells $(9.4 \%)$ tended to undergo preoperative hormonal therapy $(p=0.060)$, which led to their cancers being atrophic with inflammation. The neuroendocrine cells in these patients contained calcitoninpositive cells ( $p \leq 0.0001$ ), and calcitonin positivity showed significant association with high Gleason score $(p=0.045)$ in the group without preoperative therapy. In the group undergoing preoperative therapy, a high prostate-specific antigen titer at first admission correlated to significant biochemical
\end{abstract}

recurrence ( $p=0.003$ ). Conclusions: Neuroendocrine cells may be induced under conditions of atrophy with or without chronic inflammation in both noncancerous glands and in cancers, including calcitonin-positive cells. Neither positive neuroendocrine nor positive androgen-receptor status appears predictive for biochemical recurrence.

Copyright $\odot 2009$ S. Karger AG, Basel

\section{Introduction}

Neuroendocrine (NE) cells are normally sparsely distributed in the epithelia of many organs. Embryologically, most NE cells arise from the endoderm, rather than from the neural crest, and share a common stem cell with other epithelial cell types [1]. Dispersed NE cells are seen in the normal prostate, and contain neuropeptides including serotonin, somatostatin, calcitonin, bombesin, histamine, vasoactive intestinal peptide (VIP), $\alpha$-human chorionic gonadotropin $(\alpha-\mathrm{HCG})$, parathyroid hormonerelated protein (PTHrP) and cholecystokinin $[1,2]$. Since receptors for some of these neuropeptides are also seen in normal prostatic epithelium [3,4], it seems likely that NE cells and their products function in prostatic growth, differentiation, proliferation and modulation of surrounding target cells by intercellular paracrine or endocrine communication.

\section{KARGER}

Fax +4161306 1234

E-Mail karger@karger.ch

www.karger.com
(C) 2009 S. Karger AG, Basel

$1015-2008 / 09 / 0761-0030 \$ 26.00 / 0$

Accessible online at:

www.karger.com/pat
Noboru Konishi

Department of Pathology, Nara Medical University School of Medicine 840 Shijo-cho

Kashihara, Nara 634-8521 (Japan)

Tel. +81 744223 051, Fax +81 744235 687, E-Mail nkonishi@naramed-u.ac.jp 
NE cells are detectable in prostate cancer (PC) patients using appropriate analytical methods [5]. In one in vitro study, androgen deprivation of the androgen-dependent LNCaP cell line induced NE differentiation [6], suggesting that, at least in PC, NE cells may differentiate from malignant epithelium, though other investigators dispute this theory [7]. However, it is well known that during hormonal therapy androgen-dependent cancers often become androgen-independent, giving rise to the hypothesis that NE cells induced by androgen deprivation secrete neuropeptides that stimulate proliferation of surrounding androgen-independent cancer cells. In the androgen-independent PC cell lines PC-3 and DU-145, neuropeptide receptors are expressed on the cytoplasmic membranes and exposure to calcitonin, neurotensin and/ or PTHrP has been shown to promote cell proliferation in these lines [4, 8-11]. In a recent study, bombesin was apparently able to activate androgen receptor (AR) in PC cells under conditions of either low levels or total absence of androgen [12], suggesting that NE cells may induce AR activation via a ligand-independent pathway. Thus, depending on the analytical methods used, NE differentiation in PC may be an independent marker of poor prognosis [13-15] or an incidental and controversial phenomenon $[16,17]$.

In this study, we immunohistochemically investigated $\mathrm{NE}$ cells and their secretory role in relation to AR status in cancers of the prostate. Parameters such as cell proliferation, angiogenesis and stem or progenitor cell expression were also examined to further evaluate the biological behavior of NE cells in the prostate.

\section{Materials and Methods}

\section{Tumor Samples}

We examined a total of 96 PCs obtained from patients who had undergone radical prostatectomy. Of these patients, 46 had received preoperative hormonal therapy while 50 received no preoperative treatment. All tissue samples were fixed in $10 \%$ formalin for $48 \mathrm{~h}$ and trimmed at 5-mm intervals before processing through graded alcohols to paraffin. Paraffin blocks were then sectioned at 3- $\mu \mathrm{m}$ intervals and stained with $\mathrm{H} \& \mathrm{E}$ for histological diagnosis. For each $\mathrm{H} \& \mathrm{E}$ sample, corresponding sections, to include cancer foci of interest, were serially cut at $4-\mu \mathrm{m}$ intervals for immunohistochemistry. The clinical and pathological features of 96 selected cases were compiled and are listed in table 1 . The data collected included patient age, prostate-specific antigen (PSA) value, tumor Gleason score, tumor stage and biochemical recurrence (BR; defined by an increase in serum PSA value to $>0.2 \mathrm{ng} / \mathrm{ml}$ after radical prostatectomy).
Table 1. Clinical and pathological features of the 96 cases

$\begin{array}{lc}\text { Preoperative hormonal therapy } & 46(47.9 \%) \\ \text { No preoperative therapy } & 50(52.1 \%) \\ \text { Mean age (range), years } & 69(54-78) \\ \text { PSA at first admission (range), ng/ml } & 22.8 \pm 38.1(4.0-288.0) \\ \text { PSA at presurgery (range), ng/ml } & 7.5 \pm 8.3(0.0-50.3) \\ \text { Gleason score } & \\ 5 & 5(10.0 \%) / 2(4.3 \%) \\ 6 & 20(40.0 \%) / 11(23.9 \%) \\ 7 & 21(42.0 \%) / 8(17.4 \%) \\ 8 & 1(2.0 \%) / 7(15.2 \%) \\ 9 & 2(4.0 \%) / 4(8.7 \%) \\ 10 & 1(2.0 \%) / 1(2.2 \%) \\ \text { NA } & 0(0.0 \%) / 13(28.3 \%) \\ \text { Stage (TNM staging system) } & \\ \text { I } & 24(25.0 \%) \\ \text { II } & 29(30.2 \%) \\ \text { III } & 25(26.0 \%) \\ \text { IV } & 12(12.5 \%) \\ \text { Unknown } & 6(6.3 \%) \\ \text { Capsular invasion } & \\ + & 36(37.5 \%) \\ - & 57(59.4 \%) \\ \text { Unknown } & 3(3.13 \%) \\ \text { Biochemical recurrence } & \\ + & 30(31.3 \%) \\ \text { Unknown } & 51(53.1 \%) \\ & 15(15.6 \%)\end{array}$

For Gleason score, the first figure refers to the score of prostatectomy specimens in the group without hormonal therapy, the second to the pretherapy score of biopsy specimens in the group with therapy. TNM = Tumor, node, metastases; NA = not applicable.

\section{Immunohistochemistry}

We used chromogranin A as a neuroendocrine-specific marker to detect NE cells. We divided the samples into 2 groups, classified as low (LNE) and high (HNE) frequency based on the relative numbers of NE cells detected within the tumors. Those samples which fitted the criteria of LNE consisted of PCs with single scattered NE cells (fig. 1a); those considered to be HNE consisted of PCs with NE cell clusters of at least 10 positive cells within a field at a magnification of $\times 200$ (fig. 1b).

We immunohistochemically stained PC samples using antibodies to 10 neuropeptides: bombesin, calcitonin, adrenocorticotropic hormone (ACTH), glucagon, HCG, neurotensin, PTHrP, serotonin, thyroid-stimulating hormone (TSH) and VIP. At least 1 positive cell in the area of NE cells was regarded as showing the presence of a neuropeptide. Sections of HNE samples were also stained with antibodies to MIB-1 to assess cell proliferation, and with CD34 to evaluate angiogenesis. Based on their relative labeling indices, we subsequently divided MIB-1-positive cases into 3 groups: negative $(0 \%)$, low $(<5 \%)$ and high $(\geq 5 \%)$. In evaluating angiogenesis, we microscopically counted the capillaries around 

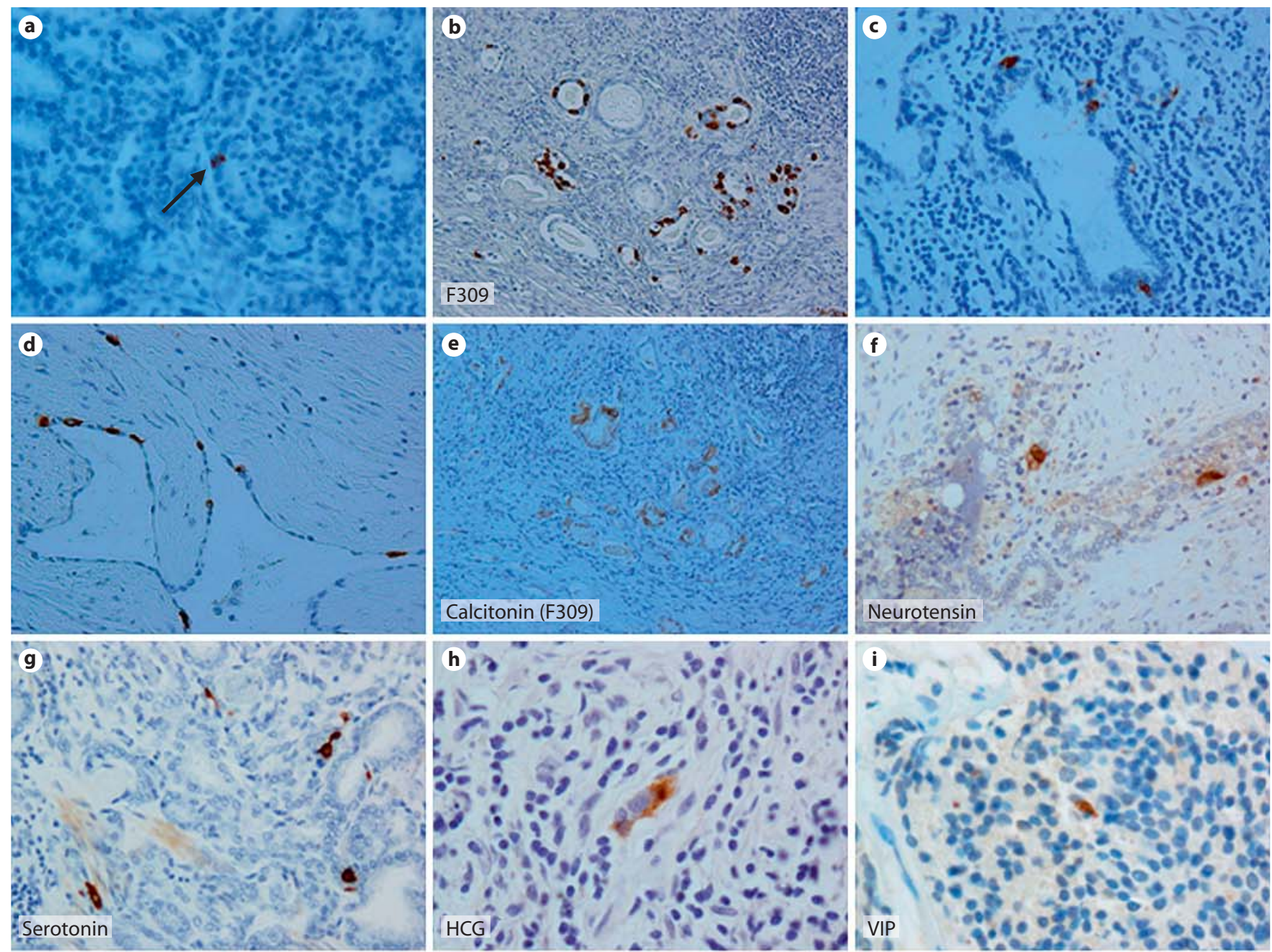

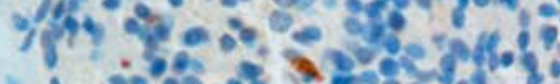

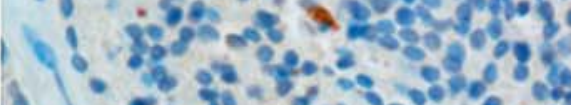
म,
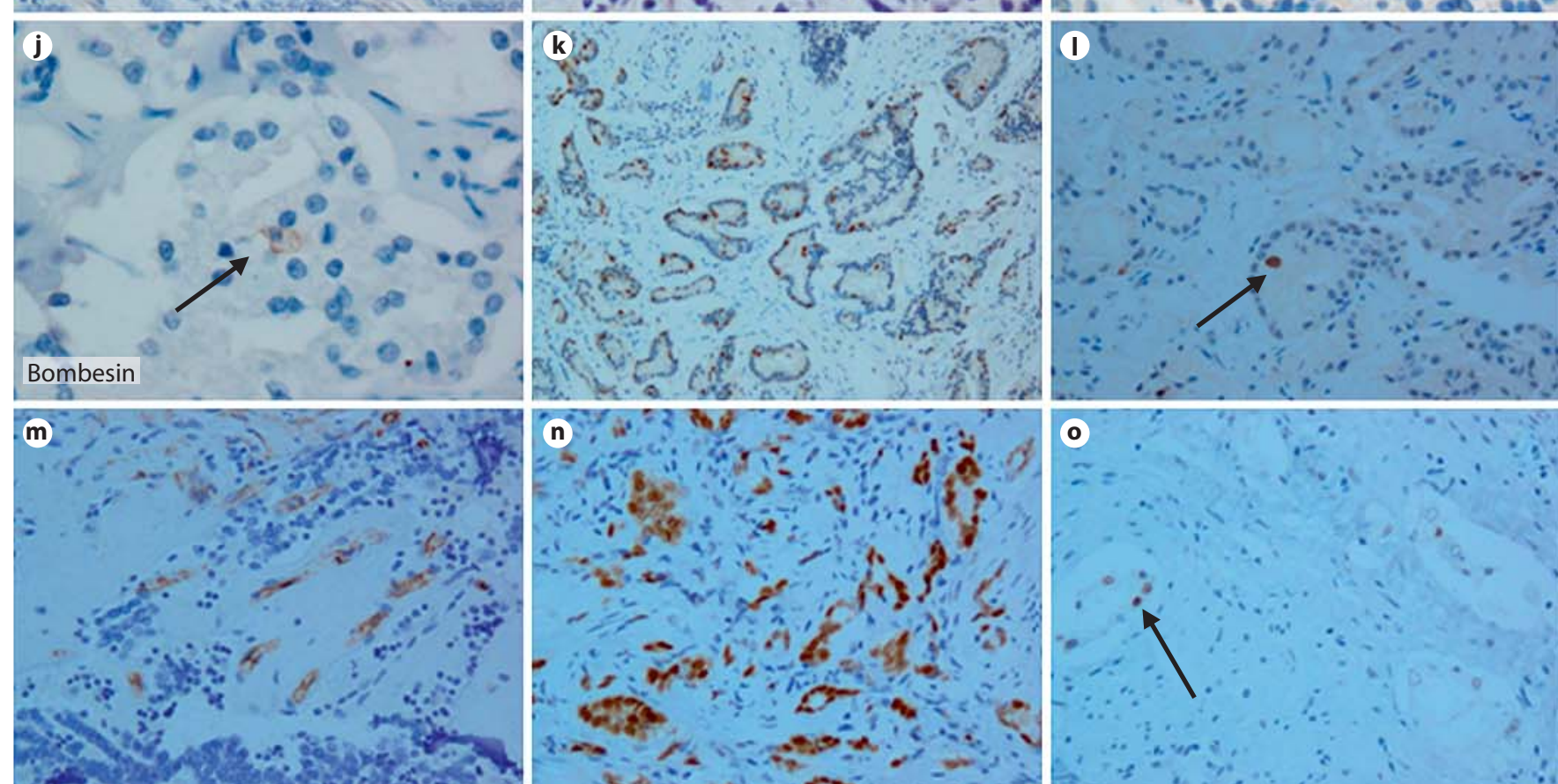
cancer foci at 3 spots in a $\times 200$ field and recorded the mean number as a microvessel count. Randomly selected NE-negative PC cases were used as controls for MIB-1 and CD34.

Based on H\&E evaluation, we selected for AR staining 19 of the 46 cases from patients exposed to hormonal therapy. These tumors were evaluated according to the sum of the percentages of cancer cells stained $(1=<25 \%, 2=26-50 \%, 3=51-75 \%$, and $4=$ $76-100 \%)$ and the intensity of nuclear staining in cancer cells $(0=$ absent, $1=$ weak, $2=$ moderate, and $3=$ strong $)$ [18]. Because a cancer stem cell theory has recently been proposed for many malignancies, including PC, we also examined the HNE cases for any association between the presence of stem cells or progenitor cells and NE differentiation using nestin, an intermediate filament protein. The procedure of immunohistochemical staining has been previously described [19]. The antibodies and their conditions are listed in table 2. The controls used were human fetal lung for bombesin, ileum for neurotensin, gastric antrum for VIP, thyroid $\mathrm{C}$ cells for calcitonin, pituitary glands for ACTH and TSH, pancreatic islets of Langerhans for glucagon, syncytotrophoblasts of chorion for HCG and glioblastoma for nestin immunostaining; positive and negative controls were stained appropriately.

\section{Statistics}

Correlations among clinicopathological factors and NE cells, neuropeptides and AR were statistically examined using MannWhitney $U$ analysis, Kruskal-Wallis analysis, $\chi^{2}$ analysis and Fisher's exact test with StatView-J 5.0 software. We determined statistical significance to be $\mathrm{p}<0.05$ for all analyses.

\section{Results}

\section{NE Cells in Nontumorous Tissues}

We frequently found NE cells in the periurethral ducts and glands of seminal vesicles and in focal atrophic glands, with or without chronic inflammation marked by lymphocyte infiltration (fig. 1c, d). NE cells were not detected in hyperplastic and cystic dilated glands within the nodules of benign prostatic hyperplasia. These findings suggest that NE cells may be derived in nontumor-

Fig. 1. Immunohistochemical staining of chromogranin A (a-d), calcitonin (e), neurotensin (f), serotonin (g), HCG (h), VIP (i), bombesin (j), MIB-1 (k, I), CD34 (m) and AR (n, o). a, b NE cells in PC. a A single NE cell is recognized in a cancerous field (arrow) from the LNE group. b Several NE cells are clustered and easily found in a field from the HNE group. Magnification $\times 200$. The HNE cases tend to show atrophic changes in cancer glands, which are frequently accompanied by lymphocyte infiltration. $\mathbf{c}, \mathbf{d ~ N E}$ cells in noncancerous glands. NE cells are frequently found in focal atrophic glands with (c) and without (d) chronic inflammation. e-j Representative cases for calcitonin, neurotensin, serotonin, HCG, VIP and bombesin (arrow) stains in PC. e Serial sec- ous tissues under certain conditions, such as glandular atrophy due to inflammation and/or hormonal therapy.

\section{NE Cells in Prostate Cancers}

Overall, we detected NE cells in 35 of the 96 PC cases, an incidence of $36.5 \%$. NE cells were slightly less frequent in tumors exposed to preoperative hormonal therapy (15 of 46 cases, or $32.6 \%$ ) and slightly more frequent in naive tumors (20 of 50 cases, or $40.0 \%$ ).

There were 9 cases classified as HNE (9.4\% of the total), which showed a relatively high frequency of NE cells within the individual tumors (fig. 1b). Their clinicopathological factors are summarized in table 3. Seven of those 9 cases had been exposed to preoperative therapy and showed atrophic glands with lymphocytic infiltration, and the NE cells were detected in a pattern similar to that seen in noncancerous tissues. All 9 HNE cases were negative for nestin expression (data not shown).

\section{NE Cells and Neuropeptide Expression}

We identified calcitonin expression in $37.1 \%$ of tumors (fig. 1e), neurotensin in $11.4 \%$ (fig. 1f), serotonin in $10 \%$ (fig. 1g), HCG in $8.6 \%$ (fig. 1h), VIP in $5.7 \%$ (fig. $1 \mathrm{i}$ ) and bombesin in only $2.9 \%$ (fig. $1 \mathrm{j}$ ) of the cancers we analyzed. ACTH, glucagon, PTHrP and TSH were not expressed in any of the cases. While the NE cells of $\mathrm{HNE}$ cases contained calcitonin-positive cells ( $\mathrm{p} \leq 0.0001$; fig. 1e; tables 3,4 ), calcitonin positivity showed significant association with high Gleason score $(p=0.045)$ in the group without preoperative therapy.

\section{Effect of NE Cells on Cell Proliferation and}

\section{Angiogenesis}

High MIB-1 indices were detected only in 2 (F189 and F312) of the 9 cases we classified as HNE (fig. 1k), the remaining 7 cases did show MIB-1 staining but with low indices (fig. 11). Among our 9 randomly-selected control

tion of (b) as a representative case from the HNE group, which demonstrates positivity for calcitonin. k, I Representative cases for MIB-1 stain in PC. $\mathbf{k}$ The HNE group consists of the cases with $\geq 5 \%$ positivity for MIB-1. I The LNE consists of the cases with $<5 \%$ positivity for MIB-1. A positive cell is shown by the arrow. m A representative case for CD34 stain in PC. Many capillaries are positive for CD34 around cancer glands. $\mathbf{n}$, o Representative cases for AR stain in PC. $\mathbf{n}$ Case with high percentage of positive cells and strong intensity for AR (corresponding to categories 4 and 3). $o$ Case with low percentage and weak intensity for AR (corresponding to categories 1 and 1; arrow). See Materials and Methods for an explanation of the categories. 
Table 2. Antibodies used for detecting NE cells, neuropeptides and androgen receptor

\begin{tabular}{lllll}
\hline Antibody & Source & Dilution & $\begin{array}{l}\text { Antigen retrieval } \\
\text { (autoclave) }\end{array}$ & $\begin{array}{c}\text { Incubation } \\
\text { time, min }\end{array}$ \\
\hline Chromogranin A & Nichirei & $1: 1$ & not performed & 60 \\
Bombesin & Dako & $1: 500$ & performed & 60 \\
Calcitonin & Dako & $1: 1$ & performed & 60 \\
ACTH & Dako & $1: 1$ & performed & 60 \\
Glucagon & Dako & $1: 1$ & performed & 60 \\
HCG & Dako & $1: 1$ & performed & 60 \\
Neurotensin & SCB & $1: 50$ & performed & 60 \\
PTHrP & SCB & $1: 500$ & performed & 60 \\
Serotonin & Dako & $1: 1$ & performed & 60 \\
TSH (0042) & Dako & $1: 50$ & performed & 60 \\
VIP & SCB & $1: 100$ & performed & 60 \\
Androgen receptor & Zymed & $1: 1$ & performed & 60 \\
Nestin & Chemicon & $1: 200$ & 60 \\
\hline
\end{tabular}

$\mathrm{ACTH}=$ Adrenocorticotropic hormone; $\mathrm{HCG}=$ human chorionic gonadotropin; PTHrP = parathyroid hormone-related protein; TSH = thyroid-stimulating hormone; VIP = vasoactive intestinal peptide.

Table 3. Clinicopathological factors of 9 cases with HNE cells

\begin{tabular}{|c|c|c|c|c|c|c|c|c|c|c|c|c|c|c|c|c|}
\hline F171 & 62 & 53.6 & treated & 0.77 & NA & pT3b & - & - & - & - & - & - & - & NA & NA & atrophic \\
\hline F192 & 67 & 34.7 & treated & 0.0 & NA (7) & pT3b & - & + & - & - & + & - & - & 61 & $\mathrm{~L}$ & atrophic \\
\hline F235 & 69 & 4.2 & not treated & - & 6 & pT3a & + & + & + & - & - & - & - & 36 & $\mathrm{~L}$ & nonatrophic \\
\hline F268 & 68 & 16.1 & treated & 0.0 & NA (6) & pT2a & - & + & - & + & - & - & - & 22 & $\mathrm{~L}$ & atrophic \\
\hline F313 & 72 & 7.6 & treated & - & NA (6) & pT2b & - & - & - & - & - & - & - & 39 & $\mathrm{~L}$ & atrophic \\
\hline F326 & 70 & 37.7 & treated & 2.2 & NA & pT3b & + & - & - & - & - & - & - & 18 & $\mathrm{~L}$ & nonatrophic \\
\hline
\end{tabular}

PSA 1 = PSA level at first admission; Therapy = preoperative hormonal therapy; PSA 2 = PSA level at presurgery; GS = Gleason score (biopsy score before therapy); $\mathrm{BR}=$ biochemical recurrence; $\mathrm{MC}=$ microvessel count; Glands = state of cancer glands; $+=$ present; - = absent; $\mathrm{H}=$ high; $\mathrm{L}=$ low; $\mathrm{NA}=$ not available.

samples (tumors with no evidence of NE cells), we had 1 case with a high MIB-1 index and 8 cases with low indices. We were unable to detect any significant correlation between cell proliferation and the presence of NE cells or calcitonin expression (table 5).

As regards angiogenesis, we saw no significant correlation in CD34 immunopositivity with tissue NE cell density among the HNE and control groups. Under $\times 200$ magnification, the mean number of CD34-positive capillaries was 29 (range 6-61) in HNE cancers and 21 (range 10-36) in NE cell-negative tumors (fig. $1 \mathrm{~m}$ ).
Preoperative therapy did not significantly affect cell proliferation $(p=0.464)$ or angiogenesis $(p=0.505)$ in the HNE group.

\section{Androgen Receptor in Prostate Cancers}

Although the percentage of AR-positive cells and their staining intensities varied, all 19 cases receiving preoperative hormone therapy were positive for AR. In terms of specific percentages per staining category, $36.8 \%$ (7/19) of cases were scored as 1, 15.8\% (3/19) scored as 2, 21.1\% $(4 / 19)$ scored as 3, and $26.3 \%$ (5/19) of cases were classi- 
Table 4. Relationship between NE cells and clinicopathological factors

\begin{tabular}{|c|c|}
\hline Factor & $\mathrm{p}$ value \\
\hline \multicolumn{2}{|l|}{ NE (whole sample) } \\
\hline Age & 0.8632 \\
\hline PSA 1 & 0.5565 \\
\hline PSA 2 & 0.5652 \\
\hline Preoperative therapy & 0.4523 \\
\hline Stage & 0.1953 \\
\hline Biochemical recurrence & 0.1705 \\
\hline \multicolumn{2}{|l|}{ HNE (whole sample) } \\
\hline Age & 0.2341 \\
\hline PSA 1 & 0.7610 \\
\hline PSA 2 & $0.0465^{*}$ \\
\hline Preoperative therapy & 0.0596 \\
\hline Gleason score & 0.27 \\
\hline Stage & 0.1744 \\
\hline Biochemical recurrence & 0.8072 \\
\hline Calcitonin & $<0.0001^{*}$ \\
\hline \multicolumn{2}{|l|}{ HNE (preoperative therapy) } \\
\hline Age & 0.0982 \\
\hline PSA 1 & 0.5892 \\
\hline PSA 2 & 0.8268 \\
\hline Gleason score & 0.74 \\
\hline Stage & 0.1861 \\
\hline Biochemical recurrence & $>0.9999$ \\
\hline Androgen receptor (percentage) & 0.6129 \\
\hline \multicolumn{2}{|l|}{ BR (preoperative therapy) } \\
\hline PSA 1 & $0.0348^{*}$ \\
\hline PSA 2 & 0.5228 \\
\hline Stage & 0.4895 \\
\hline \multicolumn{2}{|l|}{ HNE (no preoperative therapy) } \\
\hline Age & 0.9580 \\
\hline PSA 1 & 0.1022 \\
\hline Gleason score & 0.68 \\
\hline Stage & 0.8104 \\
\hline Biochemical recurrence & 0.8258 \\
\hline \multicolumn{2}{|l|}{ BR (no preoperative therapy) } \\
\hline PSA 1 & 0.3316 \\
\hline Stage & 0.4124 \\
\hline
\end{tabular}

* Significant $\mathrm{p}$ value. NE = All cases with NE cells; PSA $1=$ PSA level at first admission; PSA $2=$ PSA level at presurgery.

fied as 4 . When defined according to the degree of nuclear staining intensity, $0(0 \%)$ were in group 0, $9(47.4 \%)$ were in group 1, 3 (15.8\%) were in group 2 and 7 (36.8\%) were in group 3 . Representative cases with a high staining percentage and strong staining intensity (corresponding to percentage category 4 and intensity category 3 ) and a low percentage and weak intensity (corresponding to per-
Table 5. Biological factors of NE cells and calcitonin

\begin{tabular}{ll}
\hline Factor & p value \\
\hline HNE & \\
CD34, microvessel count & 0.2472 \\
MIB-1 & 0.9293 \\
Calcitonin & \\
CD34, microvessel count & 0.4795 \\
MIB-1 & 0.0865 \\
\hline
\end{tabular}

centage category 1 and intensity category 1 ) are illustrated in figure $1 \mathrm{n}$ and $\mathrm{o}$.

\section{Analysis of Clinicopathology and NE Cell Frequency}

We analyzed clinicopathological factors for the presence and relative numbers of NE cells within tumors to see if there were any functional correlations; these are summarized in table 4. The Gleason scores of biopsy specimens obtained prior to the start of preoperative hormone therapy are substituted for Gleason scores assigned after tumor excision so that comparisons could be made with scores for untreated tumors. HNE cases showed no significant correlation with Gleason score, tumor stage, $\mathrm{BR}$ or AR expression. AR expression alone did not significantly correlate with Gleason score, tumor stage or $\mathrm{BR}$. However, low presurgical PSA values were significantly associated with HNE cell populations $(\mathrm{p}=0.047)$ and high Gleason scores significantly correlated with both high presurgical PSA levels $(\mathrm{p}=0.021)$ and high tumor staging $(\mathrm{p}=0.034)$. High PSA levels at first admission were significantly associated with BR only in patients undergoing preoperative hormone therapy $(\mathrm{p}=$ 0.0348 ). High Gleason scores were also significantly correlated with high tumor stage $(\mathrm{p}=0.027)$ and with the presence of capsular invasion $(\mathrm{p}=0.047)$.

\section{Discussion}

The function of NE cells and the method of their differentiation in PCs are still unclear. In noncancerous tissue, NE cells were not found in hyperplastic prostate tissue, but they tended to be present in atrophic glands resulting from certain conditions, such as inflammation and/or hormonal therapy. The finding that NE cells are more distributed in atrophic glands has been reported previously [1], which may provide a clue to NE differentiation. NE cells contain various neuropeptides 
that may stimulate proliferation of surrounding cells. De Marzo et al. [20] proposed a model of proliferative inflammatory atrophy (PIA) as a precancerous lesion, in contrast to prostatic atrophy with inflammation. PIA is highly immunopositive for MIB-1 [21], and there appears to be a transition from PIA to high-grade prostatic intraepithelial neoplasia-like lesions [22]. The higher than expected numbers of NE cells we detected in our samples of noncancerous atrophic glands with inflammation may have been due to inadvertent inclusion of some PIA tissues.

While some studies have found NE cells in up to $100 \%$ of PCs surveyed [5], we detected NE cells in $36.5 \%$ of our PC samples overall. Only $9.4 \%$ of PC cases (9/96) were categorized as HNE in our study, but even within this group, NE cells tended to be found more often and more densely in chronically inflamed atrophic glands resulting from preoperative hormonal therapy and without significant correlation to proliferative activity, as indicated by the relatively low levels of MIB-1 immunostaining. This suggests that NE cells may be induced in areas of PC that are biologically similar to noncancerous atrophic glands. It may be that NE differentiation is induced by certain conditions causing glandular atrophy, notably by cytokines released by lymphocytes in cases of chronic inflammation. Paracrine secretion of neuropeptides by NE cells possibly functions to enable the glands only to recover from insult, or the proliferative effect of neuropeptides may be gentler in vivo. Interleukin- 6 and interferon- $\gamma$ are mentioned as candidates for cytokines, which may induce NE differentiation [23, 24].

The expression of nestin, a stem cell-associated intermediate filament, is now known to characterize cancer cells and stem or progenitor cells in a variety of tumor lineages. Associations of nestin expression, androgen withdrawal and metastatic potential have been confirmed in PCs [25]. Based on this claim, PC treated with hormonal therapy is expected to include nestin-positive cells. However, all 9 of our HNE cases were completely negative. This may be due to the fact that these 9 HNE samples were not from clinically metastatic disease and we may have been observing an early stage of NE differentiation.

The most commonly identified neuropeptide in our tumor samples was calcitonin, which was detected in $37.1 \%$ of the cases. This was followed by neurotensin in $11.4 \%$ of tumors, serotonin in $10 \%$, HCG in $8.6 \%$, VIP in $5.7 \%$ and bombesin in $2.9 \%$. We did not detect ACTH, glucagon, PTHrP or TSH in any sample. This is in marked contrast to previously reported PC neuropeptide profiles that have shown $5-8 \%$ of tumors to be positive for calcitonin, $0 \%$ for neurotensin, $0-54 \%$ for serotonin, $22 \%$ for HCG, $4 \%$ for bombesin, 0 to $<5 \%$ for ACTH, $0 \%$ for glucagon, $100 \%$ for PTHrP and $0 \%$ for TSH [26-28]. We could find no report for the frequency of VIP in PC. It is noteworthy that the NE cells of HNE cases contain calcitonin-positive cells ( $\mathrm{p} \leq 0.0001)$. Calcitonin induces proliferation in vitro in the androgen-independent PC-3 and DU-145 cancer cell lines $[8,29]$, and is correlated with angiogenesis in vivo through its effect on endothelial cells [30], resulting in tumor growth. Regrettably, calcitonin-positive HNE cases were not significantly associated with an increased proliferation rate in surrounding tissues or with stromal angiogenesis in this study. This may have been due to experimental conditions such as the small number of HNE cases and the limited area examined. Nonsignificant results may have occurred as a result of the complexity of the in vivo environment, for example, the time interval from calcitonin secretion to react with the surrounding cells or the inappropriate concentration of calcitonin secreted. Further study may be required. However, in the tumors from patients with no preoperative therapy, the presence of calcitonin was significantly associated with a high Gleason score ( $\mathrm{p}=$ 0.045 ), suggesting a relation to cancer aggressiveness or infiltration. In a spheroid disaggregation/migration assay, calcitonin significantly enhanced disaggregation/ migration of PC-3M spheroids, altered the surface activity of adhesion molecules, and stimulated the secretion of gelatinases (MMP-2 and MMP-9) from PC-3M cells [31, 32].

We found AR expression in all cases treated preoperatively with hormonal therapy but we did not find any significant correlation between AR expression, the presence of NE cells or BR. This expression pattern of AR in relation to NE differentiation is in line with previous observations in PC [33], and these facts suggest that neuropeptides from NE cells do not affect the AR expression status of surrounding cancer cells. After androgen-deprivation therapy, AR-positive cancer cells are not predictive of the time to progression [34], suggesting that activation of AR signaling is directly caused by neuropeptides from $\mathrm{NE}$ cells independently of the AR expression status.

In examining the relationships between clinicopathological parameters, we were able to detect significant positive associations only for PSA levels and Gleason scores: high presurgical PSA titers were predictive of tumors with both high Gleason ratings and pathology grade. Elevated PSA levels prior to preoperative androgen ablation were significantly correlated to tumor recurrence. Low 
presurgical PSA values were significantly associated with high tumor NE cell counts in a subset of lesions. Although these HNE tumors represented a small percentage (9.4\%) of the total number of tumors in this study, most of these tumors $(77.8 \%)$ were from patients who had undergone preoperative hormone therapy, and the higher frequency of NE cells is probably related to the therapy-induced glandular atrophy with or without inflammation, which appears to promote their differentiation.

In summary, we believe that NE cells may be induced under conditions of atrophy with or without chronic inflammation in both noncancerous glands and in cancers exposed to androgen-deprivation therapy, including calcitonin-positive cells, which may affect surrounding cells independently of the AR expression status. However, neither positive NE nor positive AR status appears predictive for biological tumor recurrence in prostatic cancers.

\section{Acknowledgments}

The authors thank Lota Riu and Nobuko Yosio for their excellent technical assistance.

\section{References}

1 Delellis RA, Dayal Y: The neuroendocrine system; in Mills SE (ed): Histology for Pathologists, ed 3. Philadelphia, Lippincott Williams \& Wilkins, 2007, pp s1189-s1210.

2 Huang J, Yao JL, di Sant'Agnese PA: Neuroendocrine differentiation in prostate cancer; in Kirby RS, Partin AW, Feneley MR, Parsons JK (eds): Prostate Cancer, Principles and Practice. New York, Taylor \& Francis, 2006, pp 143-150.

-3 Dizeyi N, Konrad L, Bjartell A, Wu H, Gadaleanu V, Hansson J, Helboe L, Abrahamsson PA: Localization and mRNA expression of somatostatin receptor subtypes in human prostatic tissue and prostate cancer cell lines. Urol Oncol 2002;7:91-98.

-4 Wu G, Burzon DT, di Sant'Agnese PA, Schoen S, Deftos LJ, Gershagen S, Cockett AT: Calcitonin receptor mRNA expression in the human prostate. Urology 1996;47: 376-381.

5 Abrahamsson PA, Wadstrom LB, Alumets J, Falkmer S, Grimelius L: Peptide-hormoneand serotonin-immunoreactive tumour cells in carcinoma of the prostate. Pathol Res Pract 1987;182:298-307.

-6 Burchardt T, Burchardt M, Chen MW, Cao Y, de la Taille A, Shabsigh A, Hayek O, Dorai T, Buttyan R: Transdifferentiation of prostate cancer cells to a neuroendocrine cell phenotype in vitro and in vivo. J Urol 1999; 162:1800-1805.

7 Bonkhoff H, Remberger K: Differentiation pathways and histogenetic aspects of normal and abnormal prostatic growth: a stem cell model. Prostate 1996;28:98-106.

8 Larran J, Salido M, Aparicio J, Lopez A, de Palacio ML, Vilches J: In vitro characterization of bombesin and calcitonin on the proliferation of PC3, Du 145 and LNCaP cancer prostatic cell lines. Int J Dev Biol 1996;suppl 1:275S-276S
-9 Sun B, Halmos G, Schally AV, Wang X, Martinez M: Presence of receptors for bombesin/ gastrin-releasing peptide and mRNA for three receptor subtypes in human prostate cancers. Prostate 2000;42:295-303.

10 Tovar Sepulveda VA, Falzon M: Parathyroid hormone-related protein enhances PC-3 prostate cancer cell growth via both autocrine/paracrine and intracrine pathways. Regul Pept 2002;105:109-120.

11 Seethalakshmi L, Mitra SP, Dobner PR, Menon M, Carraway RE: Neurotensin receptor expression in prostate cancer cell line and growth effect of NT at physiological concentrations. Prostate 1997;31:183-192.

12 Dai J, Shen R, Sumitomo M, Stahl R, Navarro D, Gershengorn MC, Nanus DM: Synergistic activation of the androgen receptor by bombesin and low-dose androgen. Clin Cancer Res 2002;8:2399-2405.

13 Weinstein MH, Partin AW, Veltri RW, Epstein JI: Neuroendocrine differentiation in prostate cancer: enhanced prediction of progression after radical prostatectomy. Hum Pathol 1996;27:683-687.

- 14 Bollito E, Berruti A, Bellina M, Mosca A, Leonardo E, Tarabuzzi R, Cappia S, Ari MM, Tampellini M, Fontana D, Gubetta L, Angeli A, Dogliotti L: Relationship between neuroendocrine features and prognostic parameters in human prostate adenocarcinoma. Ann Oncol 2001;12(suppl 2):S159-S164.

15 Gunia S, Albrecht K, Koch S, Herrmann T, Ecke T, Loy V, Linke J, Siegsmund M, May M: Ki67 staining index and neuroendocrine differentiation aggravate adverse prognostic parameters in prostate cancer and are characterized by negligible inter-observer variability. World J Urol 2008;26:243-250.

16 Noordzij MA, van der Kwast TH, van Steenbrugge GJ, Hop WJ, Schroder FH: The prognostic influence of neuroendocrine cells in prostate cancer: results of a long-term follow-up study with patients treated by radical prostatectomy. Int J Cancer 1995;62:252258.
17 Steineck G, Reuter V, Kelly WK, Frank R, Schwartz L, Scher HI: Cytotoxic treatment of aggressive prostate tumors with or without neuroendocrine elements. Acta Oncol 2002; 41:668-674.

18 Chodak GW, Kranc DM, Puy LA, Takeda H, Johnson K, Chang C: Nuclear localization of androgen receptor in heterogeneous samples of normal, hyperplastic and neoplastic human prostate. J Urol 1992;147:798-803.

19 Konishi N, Tsujikawa K, Yamamoto H, Ishida E, Nakamura M, Shimada K, Yane K, Yamashita H, Noguchi S: Overexpression of leukocyte common antigen (LAR) P-subunit in thyroid carcinoma. Br J Cancer 2003;88: 1223-1228.

20 De Marzo AM, Marchi VL, Epstein JI, Nelson WG: Proliferative inflammatory atrophy of the prostate: implications for prostatic carcinogenesis. Am J Pathol 1999;155:19851992.

21 Faith D, Han S, Lee DK, Friedl A, Hicks JL, De Marzo AM, Jarrard DF: P16 is upregulated in proliferative inflammatory atrophy of the prostate. Prostate 2005;65:73-82.

22 Putzi MJ, De Marzo AM: Morphologic transitions between proliferative inflammatory atrophy and high-grade prostatic intraepithelial neoplasia. Urology 2000;56:828-832.

23 Untergasser G, Plas E, Pfister G, Heinrich E, Berger P: Interferon-gamma induces neuroendocrine-like differentiation of human prostate basal-epithelial cells. Prostate 2005; 64:419-429.

24 Lee SO, Chun JY, Nadiminty N, Lou W, Gao AC: Interleukin- 6 undergoes transition from growth inhibitor associated with neuroendocrine differentiation to stimulator accompanied by androgen receptor activation during LNCaP prostate cancer cell progression. Prostate 2007;67:764-773. 
25 Kleeberger W, Bova GS, Nielsen ME, Herawi M, Chuang AY, Epstein JI, Berman DM: Roles for the stem cell associated intermediate filament nestin in prostate cancer migration and metastasis. Cancer Res 2007;67: 9199-9206.

26 di Sant'Agnese PA, de Mesy Jensen KL: Neuroendocrine differentiation in prostatic carcinoma. Hum Pathol 1987;18:849-856.

27 Asadi F, Farraj M, Sharifi R, Malakouti S, Antar S, Kukreja S: Enhanced expression of parathyroid hormone-related protein in prostate cancer as compared with benign prostatic hyperplasia. Hum Pathol 1996;27: 1319-1323.

28 Bostwick DG, Dousa MK, Crawford BG, Wollan PC: Neuroendocrine differentiation in prostatic intraepithelial neoplasia and adenocarcinoma. Am J Surg Pathol 1994;18: $1240-1246$
29 Jongsma J, Oomen MH, Noordzij MA, Romijn JC, van Der Kwast TH, Schroder FH, van Steenbrugge GJ: Androgen-independent growth is induced by neuropeptides in human prostate cancer cell lines. Prostate 2000; 42:34-44.

30 Chigurupati S, Kulkarni T, Thomas S, Shah G: Calcitonin stimulates multiple stages of angiogenesis by directly acting on endothelial cells. Cancer Res 2005;65:8519-8529.

31 Sabbisetti VS, Chiruqupati S, Thomas S, Vaidya KS, Reardon D, Chriva-Internati M, Iczkowski KA, Shah GV: Calcitonin increases invasiveness of prostate cancer cells: role for cyclic AMP dependent protein kinase A in calcitonin action. Int J Cancer 2005; 117 : 551-560.
2 Thomas S, Chriva-Internati M, Shah GV: Calcitonin receptor-stimulated migration of prostate cancer cells is mediated by urokinase receptor-integrin signaling. Clin Exp Metastasis 2007;24:363-377.

33 Theodoropoulos VE, Tsigka A, Mihalopoulou A, Tsoukala V, Lazaris AC, Patsouris E, Ghikonti I: Evaluation of neuroendocrine staining and androgen receptor expression in incidental prostatic adenocarcinoma: prognostic implications. Urology 2005;66: 897-902.

34 Sadi MV, Walsh PC, Barrack ER: Immunohistochemical study of androgen receptors in metastatic prostate cancer: comparison of receptor content and response to hormonal therapy. Cancer 1991;67:3057-3064. 